\title{
Phemiere Educandum
}

Premiere Educandum: Jurnal Pendidikan Dasar dan Pembelajaran

Volume 11 (2) 307 - 312 December 2021

ISSN: 2088-5350 (Print) / ISSN: 2528-5173 (Online)

Doi: $10.25273 /$ pe.v11i2.8640

The article is published with Open Access at: http://e-journal.unipma.ac.id/index.php/PE

\section{Student's Perception of Learning E-Learning Based}

Nur Ahyani $\bowtie$, Universitas PGRI Palembang

Wahid, Universitas PGRI Palembang

$\triangle$ nurahyani01jurnal@gmail.com

\begin{abstract}
The purpose of this study was to determine students' perceptions of E-learning based learning in the 2019/2020 even semester lectures. The population of this research is the postgraduate students of PGRI Palembang University with a sample of 81 students taking ICT and Educational Innovation courses. This research is a descriptive study. The research data was taken using a questionnaire about readiness to take E-learning, the benefits of E-learning, constraints on E-learning, and E-learning interactions. Data were analyzed using a percentage of student responses to the questionnaire given. The results showed that seen from the responses of students who agreed to the readiness to take E-learning, it was 78\%. Responses to the benefits of E-learning learning $67 \%$ who agreed, $68 \%$ of the responses to the constraints of E-learning learning agreed. The indicators of interaction between E-learning and learning were responded to by several 62 students, it can be concluded that students' perceptions of E-learning learning are quite good.
\end{abstract}

Keyword: Perception, E-Learning, Learning

Received 11 February 2021; Accepted 15 November 2021; Published 31 December 2021

Citation: Ahyani, N., \& Wahid, W. (2021). Student's Perception of Learning E-Learning Based. Premiere Educandum : Jurnal Pendidikan Dasar dan Pembelajaran, 11(1), 307 - 312.

Doi.org/10.25273/pe.v11i2.8640

\section{(cc) BY-NC-SA}

Published by Universitas PGRI Madiun. This work is licensed under the Creative Commons Attribution-NonCommercialShareAlike 4.0 International License. 


\section{INTRODUCTION}

Information and Communication Technology (ICT) is experiencing rapid development in all fields in line with the era of globalization which requires people to adapt to these developments. One of the fields that must adapt to these developments in the field of education. Efforts that can be made for the world of education are by utilizing ICT in the learning process. The application of technology in education is known as ICT. ICT is an integral part of the learning process through the distance learning process (E-learning). The integration of ICT into the learning process will improve ICT Literacy, build knowledge-based community characteristics, and increase the effectiveness and efficiency of the learning process itself (Sari, 2017: 76).

According to Miarso (2004), currently, the world is entering the fifth revolution marked by the development of information and communication technology, while the characteristics are: 1) the development of learning outside of campus as a form of continuing education, 2) students gain greater access from various sources, 3) the library as a learning resource center is the dominant characteristic of the campus, 4) the campus buildings are scattered with the core campus in the center and the satellite campuses in the community, 5) the demand for students to master technology, 6) the growth of new professions in media and technology, and 7) students are required to learn more independently. This opinion is in line with Khusriyah and Hakim (2019) who state that the development of information and communication technology (ICT) in the Industrial Age 4.0 has had a major influence on the learning process, besides that access to technology has been used by teachers to improve the quality of education. E-learning class is a form of internet use that can increase the role of students in the learning process. As stated by Saifudin (2018), the internet is currently an inseparable part of the lifestyle of various Indonesians. Until now, many e-learning services are available, which are managed independently by an institution using a Learning Management System (LMS), as well as those provided by third parties. The use of E-learning can increase interactivity and efficiency in learning because it is possible for students to communicate more with lecturers and colleagues and to be able to access more learning materials.

The willingness of students to use ICT in learning cannot be separated from their perceptions of the learning process with networks or E-learning. According to Nugroho, 2012 , perception is a process that starts with the use of the five senses in receiving a stimulus, then it is organized and interpreted to give rise to sensed understanding.

Regarding the use of E-learning in the learning process, PGRI Palembang University has E-learning developed with the Moodle LMS. E-learning has been used as a learning process that has been validated by the leadership of the PGRI Palembang University.

Responding to the condition of Indonesia which was affected by COVID 19, Elearning is one of the right means to continue the lecture process which does not allow face-to-face lectures. All lecturers at the PGRI Palembang University have utilized Elearning, both as a forum for uploading Semester Implementation Plans (RPS), uploading lecture materials, as well as in online lecture activities (online), such as discussions, chatting, submitting assignments, midterm exams (UTS) as well as semester exams (UAS), and other online activities.

To see the implementation of E-learning-based lectures, it is necessary to study more deeply by looking at the perceptions of students towards the E-learning lecture process, so that it can be seen in the form of E-learning based lectures that students want. This study aims to determine students' perceptions of E-learning-based lectures. 


\section{METHODS}

This research is included in descriptive research, by surveying students taking ICT and Educational Innovation courses in the Postgraduate Education Management Study Program at PGRI Palembang University with a sample of 81 students. The research variable is E-learning based learning. The data collection technique used a closed questionnaire with indicators: 1) the readiness of students in taking e-learning learning with indicators of understanding the internet, looking for learning resources on the internet, understanding e-learning learning, being able to use various computer applications, having an iyernet network, using the internet, able to do tasks, have a laptop and internet network; 2) the benefits of e-learning learning with indicators can be done anytime and anywhere, organized learning process, lower costs, simple login process, easily accessible material, easy task collection and cost savings; 3 ) constraints in elearning with indicators that not all lecturers and students have internet access, the material is not extensive, login displays need instructions, unscheduled assignments, no direct supervision, difficult to understand learning materials, expensive infrastructure preparation .; 4) interaction between e-learning lectures with indicators provides ease of interaction, interaction with lecturers is more familiar, easy to address problems to lecturers, miscommunication with lecturers often occurs, it is easy to collaborate with lecturers, gives more difficulties, easy to interact with fellow students. Data were collected using a Likert scale, closed questionnaire type, and in the form of a checklist, a questionnaire totaling 30 statement items. The population was students of the Postgraduate Education Management Study Program at PGRI Palembang University, while the sample was taken from students of the 2019/2020 class who took ICT and Educational Innovation courses totaling 81 students.

The stages taken in this research are, a) compiling a questionnaire instrument that will be used for data collection, b) validity of the questionnaire that has been compiled using expert opinion conducted by two instrument experts who understand e-learning, c) collecting data through a questionnaire which has been validated from students who are used as research samples, d) data obtained from students is in the form of qualitative and quantitative data which are then analyzed descriptively.

\section{RESULTS AND DISCUSSION}

The data obtained through a questionnaire about the readiness of students in e-learning learning after being converted into a percentage obtained the following results.

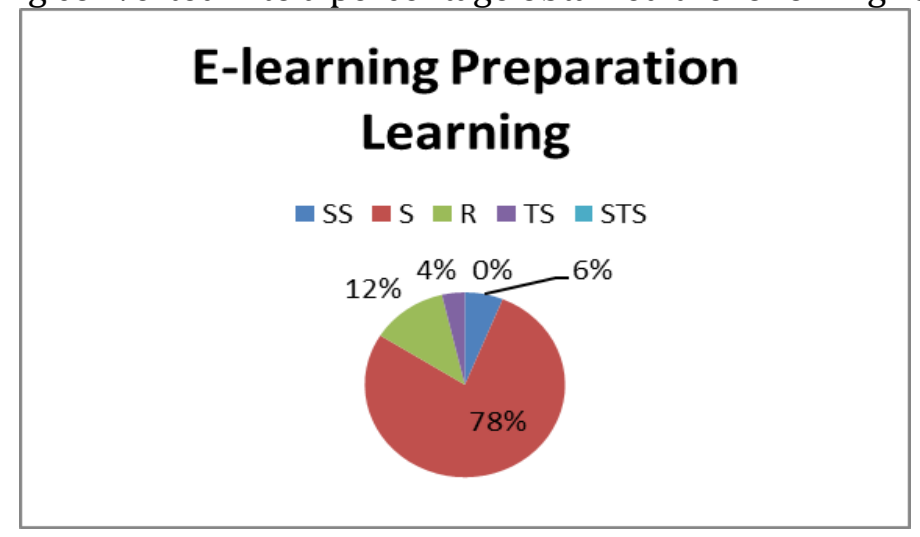

Figure 1. E-learning preparation 
Based on the results of the questionnaire in Figure 1, the data of students who started their readiness to take E-learning learning was $78 \%$, this indicates that in general students stated that they were ready to take E-learning lectures with the knowledge and knowledge. Amenities. Students know about internet and e-learning, laptop facilities, networking. This is in line with the results of research by Rivalina, R (2017) which states that to support the e-learning learning process students must have adequate knowledge of e-learning, laptops, and internet facilities.

Data about the benefits of E-learning learning obtained from a questionnaire is shown in the following figure.

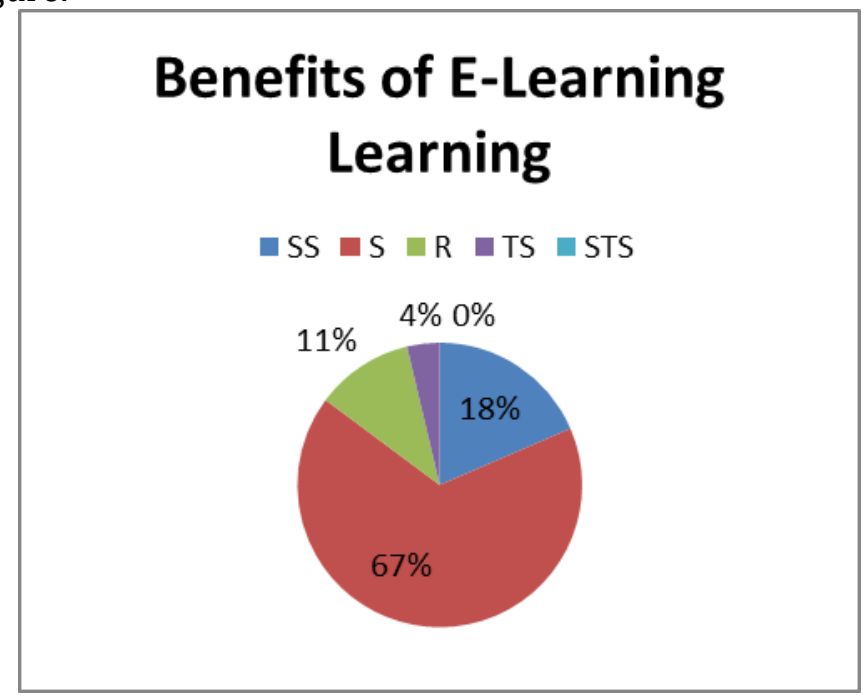

Figure 2. Benefits of E-Learning

From Figure 2 it can be seen that students agree with the benefits of e-learning, namely $67 \%$. The benefits of e-learning include learning that can be done anywhere and anytime, e-learning makes the learning process regular, e-learning costs are cheaper, materials can be accessed easily. The results of this study are in line with the research results of Mustari, A., Wiharto, M. (2019) which state that the benefits of e-learning include accelerating work, increasing effectiveness, increasing performance, increasing performance and productivity, and making work easier. The results of research by Saifuddin, Fuad, M. (2017) also stated that e-learning provides significant benefits to the learning process, namely helping readiness in learning, helping independent learning, making it easier to study material.

The e-learning constraint data obtained from the questionnaire can be seen in the following figure.

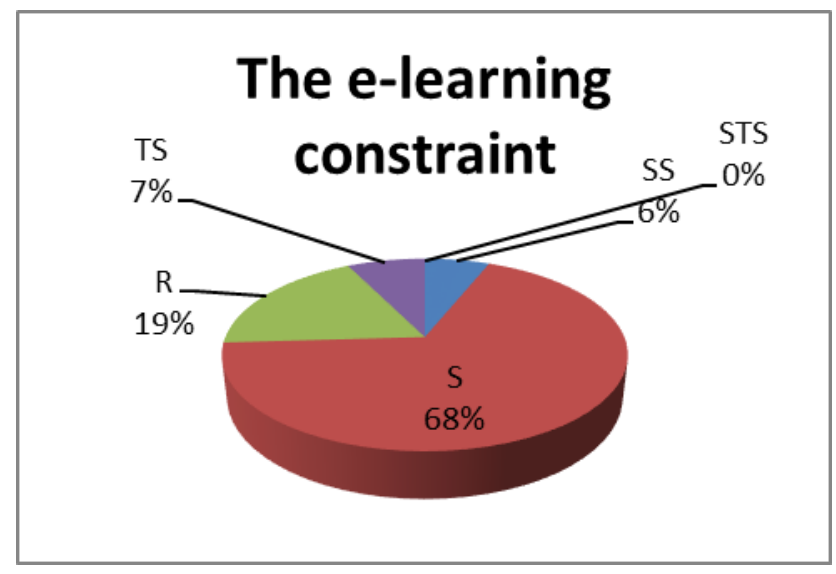

Figure 3. E-Learning Constraint 
Based on the results of the E-learning constraint questionnaire in Figure 3, it can be seen that $68 \%$ of students who agree have found problems in E-learning learning. This illustrates that students feel obstacles in learning E-learning. These constraints are that not all lecturers and students have adequate internet access, the material provided is not extensive, the login page display needs clear instructions, the assignment has not been scheduled, there is no direct supervision at the time of assignment, the learning material is poorly understood without lecturer explanation, and preparation ICT infrastructure for online learning is expensive. The results of this study are in line with the results of research and opinions (Saifuddin, Fuad, M, 2007; Both \& Borke, 2010) which state that learning needs to be developed by combining E-learning with learning models and teaching materials. according to the characteristics of the material. Another effort is to present teaching materials in various forms such as modules, videos, images, and audio adapted to the material. These efforts were made to minimize material constraints on elearning which were less extensive and interesting.

Questionnaire data about E-learning Learning Interaction can be seen in the following figure.

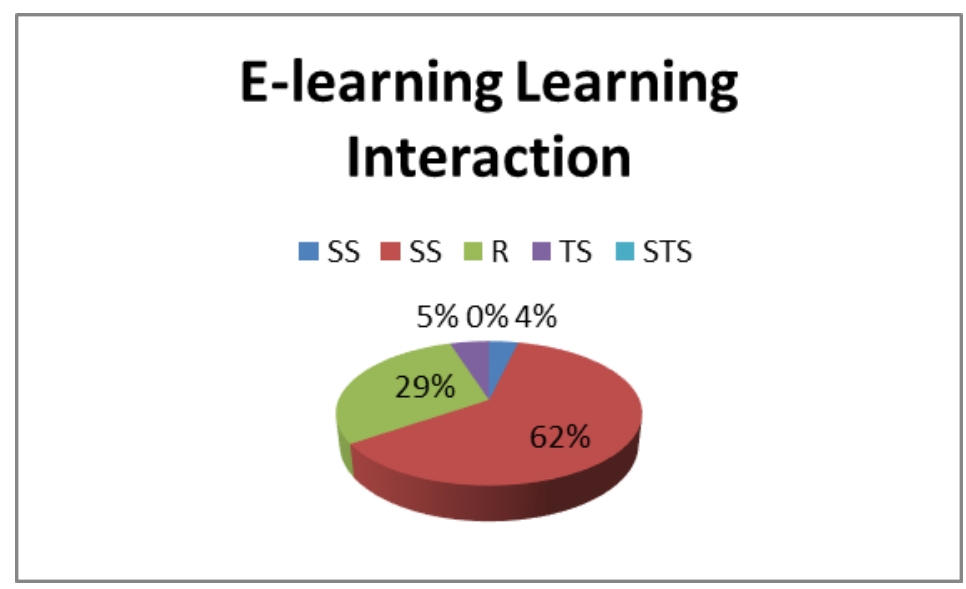

Figure 4. E-Learning Interaction

Based on the results of the interaction questionnaire in online learning in Figure 4, it can be seen that $62 \%$ of students agree with the interaction statement in online learning which includes e-learning, making it easier for students to interact with lecturers. . For this reason, e-learning provides more possibilities. for students to interact with lecturers rather than face to face. Then the statement states the problems faced by students in lectures to lecturers are more comfortable, interaction between students is easy. As stated by Alimudin, Rahmana, and Najib (2015) students can share information and can access teaching materials at any time and repeatedly, so that students have a better mastery of the material.

\section{CONCLUSION}

Based on the results of the study, it showed that the students' perceptions of E-learning based learning were in a fairly good category. Students state readiness in participating in E-learning learning. Students feel the benefits of E-learning. Students stated that there were obstacles in implementing E-learning-based learning, one of which was the cost of Elearning learning infrastructure which was expensive, but students felt that E-learning made easier interactions with lecturers and between students, especially in the exchange of information. 


\section{REFERENCE}

1. Alimudun., R, T., \& Najib, M. (2015). Intensitas Penggunaan E-learning dalam Menunjang Pembelajaran Mahasiswa Program Sarjana Universitas Hasanudin. Jurnal Komunikasi KAREBA. 4(4).

2. Both, D., \& Bourke, J. (2010). Getting Started With Blended Learning. Quensland: Graffith University.

3. Khusniyah, K \& Hakim, H. (2019). Efektifitas Pembelajaran Berbasis daring: Sebuah Bukti Pada Pembelajaran bahasa Inggris. Jurnal Tatsqif, 17(1), 19-33.

4. Mustari, A., \& Wiharto, M. (2019). Persepsi Mahasiswa Terhadap Penggunaan Program E-Learning berbasis LMS pada Mata Kuliah Teknologi Budidaya Perikanan. Prosiding Seminar Nasional. Makasar: Universitas Negeri Makasar.

5. Miarso, Y. (2004). Menyemai Benih Teknologi Pendidikan. Jakarta: Pustekkom DIKNAS

6. Nugroho, S. (2012). Profesionalisme Guru SD Negeri Se-Kecamatan Warung Asem Kabupaten Batang (Suatu tinjauan aspek persepsi guru tentang kepemimpinan kepala sekolah dan motivasi berprestasi guru). Jurnal VARIDIKA, 24(2), 135-146.

7. Rivalina, R. 2017. Strategi Pemenfaatan E-Learning dalam Mengatasi Keterbatasan Jumlah Dosen Kwangsan, 5(2),129-145.

8. Syaifudin, M.F. (2017). E-Learning Dalam Persepsi Mahasiswa. Varia Pendidikan. 29(2). 102-109.

9. Saifuddin, M. F. (2018). Implementasi Media E-learning untuk Pendidikan karakter Bagi Peserta Didik. Jurnal Taman Cendikia. 2(1).

10. Sari. I. P. (2017). Imlementasi Pembelajaran Berbasis E-Learning Menggunakan Claroline. Research and Development Journal Of Education. 4(1).

\section{PROFILE}

Nur Ahyani is a lecturer in the History Education Program at the Universitas PGRI Palembang, Indonesia. In addition to being involved in the world of research, she is also active in the social and literacy movements.

Wahid is a lecturer in the History Education Program at the Universitas PGRI Palembang, Indonesia. He is interested in research related to social science and educational research. 